\title{
Amylin Receptor Signaling in the Ventral Tegmental Area is Physiologically Relevant for the Control of Food Intake
}

\author{
Elizabeth G Mietlicki-Baase*,', Laura E Rupprecht', Diana R Olivos', Derek J Zimmer', Mark D Alter², \\ R Christopher Pierce ${ }^{2}$, Heath D Schmidt ${ }^{2}$ and Matthew R Hayes' \\ 'Translational Neuroscience Program, Department of Psychiatry, Perelman School of Medicine at the University of Pennsylvania, Philadelphia, PA, \\ USA; ${ }^{2}$ Center for Neurobiology and Behavior, Department of Psychiatry, Perelman School of Medicine at the University of Pennsylvania, \\ Philadelphia, PA, USA
}

\begin{abstract}
The ability of amylin, a pancreatic $\beta$-cell-derived neuropeptide, to promote negative energy balance has been ascribed to neural activation at the area postrema. However, despite amylin binding throughout the brain, the possible role of amylin signaling at other nuclei in the control of food intake has been largely neglected. We show that mRNA for all components of the amylin receptor complex is expressed in the ventral tegmental area (VTA), a mesolimbic structure mediating food intake and reward. Direct activation of VTA amylin receptors reduces the intake of chow and palatable sucrose solution in rats. This effect is mediated by reductions in meal size and is not due to nausea/malaise or prolonged suppression of locomotor activity. VTA amylin receptor activation also reduces sucrose selfadministration on a progressive ratio schedule. Finally, antagonist studies provide novel evidence that VTA amylin receptor blockade increases food intake and attenuates the intake-suppressive effects of a peripherally administered amylin analog, suggesting that amylin receptor signaling in the VTA is physiologically relevant for food intake control and potentially clinically relevant for the treatment of obesity.

Neuropsychopharmacology (2013) 38, I685-1697; doi:I0.1038/npp.2013.66; published online 27 March 2013
\end{abstract}

Keywords: obesity; diabetes; IAPP; pramlintide; reward

\section{INTRODUCTION}

Amylin, also known as islet amyloid polypeptide, is a neuropeptide that is co-secreted with insulin from pancreatic $\beta$-cells (Johnson et al, 1988; Kahn et al, 1990) in response to the presence of nutrients in the digestive tract (Butler et al, 1990). Because of its potent ability to improve glycemic control (Scherbaum, 1998), the amylin analog pramlintide is FDA approved for the treatment of both type 1 and type 2 diabetes mellitus (Singh-Franco et al, 2007). In addition, amylin and amylin receptor agonists such as pramlintide and salmon calcitonin (sCT) reduce food intake and body weight (BW) when administered peripherally or into the cerebroventricular system (Chapman et al, 2007; Lutz et al, 2000; Reidelberger et al, 2002; Roth et al, 2006; Rushing et al, 2000; Smith et al, 2007), making amylinbased pharmacotherapies attractive as potential obesity treatments.

\footnotetext{
*Correspondence: Dr EG Mietlicki-Baase or Dr MR Hayes, Translational Neuroscience Program, Department of Psychiatry, Perelman School of Medicine at the University of Pennsylvania, $125 \mathrm{~S}$ 3 Ist Street, Philadelphia, PA 19104, USA. Tel: + I 2157463664 , Fax: + I 215573 204 I, E-mail: ebaase@mail.med.upenn.edu (EGM-B); Tel: + I 215573 6070, Fax: + I 215573 204l, E-mail: hayesmr@mail.med.upenn.edu (MRH)

Received 26 November 2012; revised 12 February 2013; accepted I March 2013; accepted article preview online 8 March 2013
}

Although the vast majority of reports suggest that the anorectic and BW-suppressive effects of amylin receptor activation are mediated primarily by the area postrema (AP; Lutz et al, 1998; Mollet et al, 2004; Riediger et al, 2002), a hindbrain circumventricular nucleus, the food intake-regulatory effects of amylin receptor signaling at other brain nuclei are largely unexplored. This is surprising considering the widespread distribution of central nervous system (CNS) sites that bind amylin or sCT (Beaumont et al, 1993; Christopoulos et al, 1995; Paxinos et al, 2004; Sexton et al, 1994) and the fact that amylin readily crosses the blood-brain barrier (Banks et al, 1995). Thus, given that energy balance control is distributed across the neuraxis (Grill, 2006), it is highly plausible that non-AP amylin-receptor expressing nuclei may mediate the energy balance effects of amylin. The ventral tegmental area (VTA), a mesolimbic structure well known to contribute to the regulation of food intake, especially intake of palatable foods (Narayanan et al, 2010; Vucetic and Reyes, 2010), has been overlooked in the amylin-feeding literature. Despite the fact that both amylin and sCT bind in the VTA (Paxinos et al, 2004), the role of VTA amylin receptor activation on food intake control has not been evaluated. Given the growing appreciation that obesity is linked with overconsumption of highly palatable foods (Ryan et al, 2012), it is necessary to investigate how neuroendocrine systems responsible for the regulation of 
energy balance modulate food reward via activation of hedonic/motivational structures in the CNS. Thus, the current experiments examined whether exogenous and endogenous amylin receptor signaling in the VTA of rats controls food intake and the motivation to obtain a palatable food reward.

\section{MATERIALS AND METHODS}

\section{Subjects}

Adult, male Sprague-Dawley rats (Charles River Laboratories) were individually housed in hanging wire mesh cages in a temperature- and humidity-controlled environment. Rats were maintained on a 12-h light:12-h dark cycle with standard rodent chow (Purina Rodent Chow 5001; Ralston Purina Company, St Louis, MO, USA) and water available ad libitum except where noted. All experimental procedures received approval from the University of Pennsylvania Institutional Animal Care and Use Committee.

\section{Drugs}

The amylin receptor agonist sCT (Bachem, Torrance, CA, USA) was dissolved in artificial cerebrospinal fluid (aCSF; Harvard Apparatus, Holliston, MA, USA) for central injections or sterile $0.9 \% \mathrm{NaCl}$ for peripheral injections. The amylin receptor antagonist AC187 (R\&D Systems, Minneapolis, MN, USA) was dissolved in aCSF. Dose responses for drugs were selected from the literature (Hayes et al, 2011; Lutz et al, 2000; Mollet et al, 2004; Rushing et al, 2001, 2000; Wielinga et al, 2007).

\section{Surgery}

Rats were anesthetized using a mixture of ketamine $(90 \mathrm{mg} /$ $\mathrm{kg})$, xylazine $(2.7 \mathrm{mg} / \mathrm{kg})$, and acepromazine $(0.64 \mathrm{mg} / \mathrm{kg})$ and were placed into a stereotaxic apparatus. Guide cannulae (Plastics One, Roanoke, VA, USA) were implanted and affixed to the skull with bone screws and dental cement (VTA surgeries: 26-G bilateral guide cannula, coordinates: $\pm 0.5 \mathrm{~mm}$ lateral to midline, $6.8 \mathrm{~mm}$ posterior to bregma, $6.6 \mathrm{~mm}$ ventral to skull; injector aimed $8.6 \mathrm{~mm}$ ventral to skull; third cerebroventricle (3rd ICV) surgeries: $26-\mathrm{G}$ guide cannula, coordinates: $2.0 \mathrm{~mm}$ posterior to bregma, $7.7 \mathrm{~mm}$ ventral to skull; injector aimed $9.7 \mathrm{~mm}$ ventral to skull). For all surgeries, analgesia was provided (meloxicam, $2 \mathrm{mg} / \mathrm{kg}$ ). Caudal VTA coordinates used previously by our laboratory (Alhadeff et al, 2012) were selected to avoid potential drug diffusion into hypothalamic structures that could be associated with more rostral VTA drug administration. VTA cannulae placements were verified histologically postmortem with injections of pontamine sky blue $(100 \mathrm{nl})$. A representative image of a VTA cannula injection is shown in Figure $1 \mathrm{~g}(40 \mu \mathrm{m}$ section). 3rd ICV cannulae placements were verified before testing by injecting 5-thio$d$-glucose $(210 \mu \mathrm{g} / 2 \mu \mathrm{l}$; Fisher Scientific) into the 3rd ventricle; animals with at least a twofold increase in blood glucose after injection were included in subsequent testing (Kanoski et al, 2012; Ritter et al, 1981).
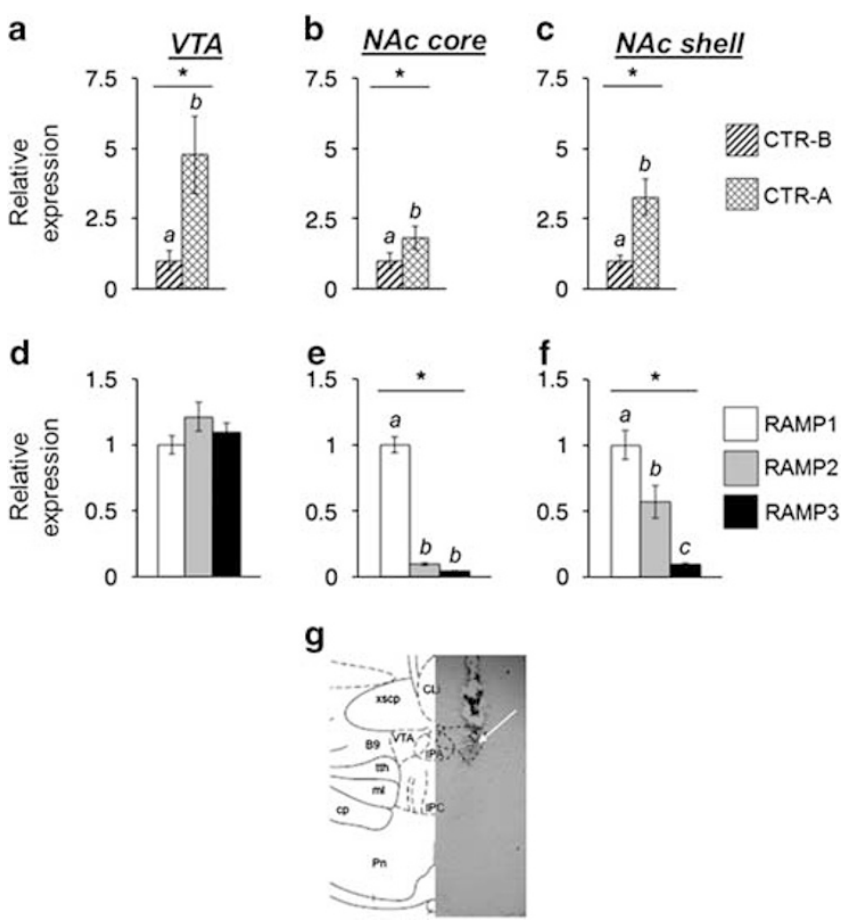

Figure I All components of the amylin receptor complex are expressed in the VTA. mRNA for CTR subtypes A and B (a-c) and RAMP subtypes I, 2 , and $3(d-f)$ is expressed in the VTA $(a, d)$, nucleus accumbens core $(b$, e), and nucleus accumbens shell (c, f). CTR-A is more highly expressed than CTR-B in all three sites $(\mathrm{a}-\mathrm{c})$, but RAMP expression differs between sites. RAMPI is the most robustly expressed subtype in the nucleus accumbens core (e) and shell ( $\mathrm{f}$, but all three RAMP subtypes are expressed at approximately equal levels in the VTA (d). mRNA expression is shown as fold change; CTR data were normalized to CTR-B levels in each site, whereas RAMP data were normalized to RAMPI levels in each site $(n=9-$ 10 rats per site; *significant main ANOVA $(P<0.05)$; within a panel, bars with different letters are significantly different from each other $(P<0.05)$ ). Data shown as mean $\pm \mathrm{SEM}$. A representative image of VTA cannula placement after pontamine sky blue injection is shown in $\mathrm{g}$.

\section{Quantitative Real-Time PCR (qPCR) Studies}

Chow-maintained rats $(n=10)$ were killed $5-6 \mathrm{~h}$ into the dark phase. Brains were rapidly removed, flash-frozen in $-70^{\circ} \mathrm{C}$ isopentane, and stored at $-80^{\circ} \mathrm{C}$ until processing. Micropunched tissue from VTA $(n=10)$, nucleus accumbens (NAc) core $(n=10)$, and NAc shell $(n=9)$ was collected from each brain. Total RNA was extracted from tissue from each site using TRIzol (Invitrogen, Grand Island, NY, USA) and the RNeasy kit (Qiagen, Valencia, CA, USA). The Advantage RT-for-PCR Kit (Clontech, Mountain View, CA, USA) was used to synthesize cDNA from $250 \mathrm{ng}$ of total RNA. Relative mRNA levels of each subtype of calcitonin receptor (CTR) and receptor activity modifying protein (RAMP) were quantified using quantitative realtime PCR. Rat GapDH (VIC-MGB) was used as an internal control. PCR reactions were completed using TaqMan gene expression kits (CTR-A: Rn01526770_m1, CTR-B: Rn01526768_m1, RAMP1: Rn01427056_m1, RAMP2: Rn00571815_m1, RAMP3: Rn00824652_g1, GapDH: Rn01775763_g1) and PCR reagents from Applied Biosystems (Grand Island, NY, USA). Samples were analyzed with the Eppendorf Mastercycler ep realplex2. Relative mRNA 
expression calculations were completed using the comparative threshold cycle method (Bence et al, 2006).

\section{Behavioral Experiments: General Methods}

All experiments used a counterbalanced, within-subjects design. Drug injections were made immediately before the onset of the dark period except where noted. For experiments measuring ad libitum food intake, weights of food hoppers were recorded to the nearest $0.1 \mathrm{~g}$ and food spillage was accounted for in cumulative intake measurements.

\section{Effect of Intra-VTA Amylin Receptor Activation on Chow Intake and Meal Patterns}

Chow-maintained rats were housed in a custom-made automated feedometer system consisting of hanging wire mesh cages with a small access hole leading to a food cup resting on an electronic scale. Weights of the rats' food cups were recorded by computer software (LabView) every $10 \mathrm{~s}$ for $24 \mathrm{~h}$. Rats $(n=11)$ received unilateral VTA injections of sCT $(0.4,0.04$, or $0.004 \mu \mathrm{g})$ or vehicle $(100 \mathrm{nl} \mathrm{aCSF})$ and $24 \mathrm{~h}$ food intake and BW change were recorded. Cumulative food intake and meal patterns were analyzed, with a meal defined as ingestion of at least $0.25 \mathrm{~g}$ of food with a minimum of $10 \mathrm{~min}$ between feeding bouts.

In a second group of rats, we tested whether any intermediate doses of $\mathrm{sCT}$ (ie, between the intra-VTA suprathreshold $(0.04 \mu \mathrm{g})$ and subthreshold $(0.004 \mu \mathrm{g})$ doses for an effect on food intake established in the first doseresponse experiment) would be effective to reduce food intake when delivered to the VTA. Rats $(n=7)$ received counterbalanced unilateral VTA injections of sCT (0.04, $0.02,0.01$, or $0.004 \mu \mathrm{g}$ ) or vehicle ( $100 \mathrm{nl} \mathrm{aCSF})$. Chow intake was measured at $1,3,6$, and $24 \mathrm{~h}$. BW change was recorded over the $24 \mathrm{~h}$ test period.

\section{Dose-Response Effects of 3rd ICV sCT on Food Intake in Ad Libitum-Fed Rats}

Chow-maintained rats $(n=14)$ received 3rd ICV injections of $\operatorname{sCT}(0.4,0.04$, or $0.004 \mu \mathrm{g})$ or vehicle $(1 \mu \mathrm{laCSF})$. Chow intake was measured at $1,3,6$, and $24 \mathrm{~h}$. BW change over the $24 \mathrm{~h}$ was recorded.

\section{Effect of Intra-VTA Amylin Receptor Activation on Pica}

Rats $(n=7)$ had ad libitum access to chow and kaolin pellets (Research Diets, New Brunswick, NJ, USA) for 1 week before testing. Subsequently, rats received unilateral VTA injections of sCT $(0.4,0.04$, or $0.004 \mu \mathrm{g})$ or vehicle $(100 \mathrm{nl} \mathrm{aCSF})$. Food and kaolin intake, as well as spillage of both substances, were measured at $24 \mathrm{~h}$; BW change over the 24 -h period was also recorded.

\section{Effect of Intra-VTA Amylin Receptor Activation or Blockade on Locomotor Activity}

Rats $(n=9)$ were habituated to square-shaped, open-field testing chambers $\left(16^{\prime} \times 16^{\prime} \times 14.75^{\prime}\right.$; San Diego Instruments, San Diego, CA, USA) for $3 \mathrm{~h}$ each day for three consecutive days before testing. Chow and water were unavailable only while rats were in the test chambers. On testing days, rats were placed into the open-field chambers $2 \mathrm{~h}$ after lights-off in order to avoid any food-related anticipatory locomotor activity associated with the onset of the dark phase. Baseline locomotor activity was monitored for $1 \mathrm{~h}$ and data were recorded by computer software (San Diego Instruments Photobeam Activity System) in 5 min bins. Next, rats received unilateral VTA injections of sCT $(0.04 \mu \mathrm{g})$, the amylin receptor antagonist $\mathrm{AC} 187(0.3 \mu \mathrm{g})$, or vehicle $(100 \mathrm{nl} \mathrm{aCSF})$ in counterbalanced order. Locomotor activity was recorded for an additional $3 \mathrm{~h}$ post injection, with total distance recorded as inches of movement on an $x-y$ axis. The first $30 \mathrm{~min}$ of data from each phase of testing (preinjection/baseline and post injection) were discarded to avoid adding variability to the data as a result of the transient increased locomotor activity observed as a result of animal handling (Skibicka et al, 2009; Skibicka and Grill, 2009). Thus, total distance from the last $30 \mathrm{~min}$ of the preinjection phase (time $-30 \mathrm{~min}$ to $0 \mathrm{~min}$ ) and the last $2.5 \mathrm{~h}$ of the post injection phase (time $30 \mathrm{~min}$ to $180 \mathrm{~min}$ ) were analyzed in $5 \mathrm{~min}$ and $30 \mathrm{~min}$ bins.

\section{Effect of Intra-VTA Amylin Receptor Activation on Ad Libitum Sucrose Intake}

Rats $(n=15)$ were trained for 1 week to consume $15 \%$ sucrose $(\mathrm{w} / \mathrm{v})$ for a $1-\mathrm{h}$ period at the same time each day, $2 \mathrm{~h}$ after the beginning of the light phase. Food and water were removed shortly after lights-on and remained unavailable until the $1 \mathrm{~h}$ sucrose access was over. Immediately before the beginning of the $1 \mathrm{~h}$ sucrose access period, rats received counterbalanced unilateral VTA injections of sCT (0.04 or $0.01 \mu \mathrm{g})$ or vehicle $(100 \mathrm{nl} \mathrm{aCSF})$. Sucrose intake was measured $( \pm 0.1 \mathrm{ml})$ every $10 \mathrm{~min}$ during the $1 \mathrm{~h}$ access period. After $1 \mathrm{~h}$, sucrose burettes were removed from the cages; chow and water were returned. Chow intake was measured for the subsequent $23 \mathrm{~h}$. BW change over the 24 -h period was recorded. Total kcal intake was calculated based on the volume of sucrose $(0.6 \mathrm{kcal} / \mathrm{ml})$ and weight of chow $(3.34 \mathrm{kcal} / \mathrm{g})$ consumed over the total 24 -h test period.

\section{Effect of Intra-VTA Amylin Receptor Activation on Sucrose Self-Administration}

Experiments were conducted in ventilated, sound-attenuating operant chambers (Med Associates, St Albans, VT, USA). Rats $(n=10)$ were trained initially to lever press for $45 \mathrm{mg}$ sucrose pellets (Research Diets) on a fixed ratio 1 (FR1) schedule of reinforcement during $1 \mathrm{~h}$ operant sessions. Once animals achieved stable responding for sucrose (defined as $<20 \%$ variation in responding over 2 consecutive days) on the FR1 schedule of reinforcement, the response requirement was increased to a FR5 schedule of reinforcement for 7 days. Rats were limited to 30 sucrose pellets within each $1 \mathrm{~h}$ operant session and had ad libitum access to lab chow (Harlan Teklad, Frederick, MD, USA) in their home cages throughout the first phase of behavioral testing. After 7 days of FR5 responding, rats received unilateral VTA injections of sCT $(0.04 \mu \mathrm{g})$ or vehicle $(100 \mathrm{nl}$ aCSF). VTA injections were given $2 \mathrm{~h}$ after the onset of the light phase. The effects of the drug on sucrose selfadministration on a progressive ratio (PR) schedule of 
reinforcement were evaluated. Under a PR schedule, the response requirement for each subsequent delivery of a sucrose pellet increases exponentially until the subject fails to meet a requirement. In the current experiments, the response requirement for the $i$ th reinforcement was given by $R(i)=\left[5 \mathrm{e}^{0.2 \mathrm{i}}-5\right]$ and the session expired when an animal took more than $30 \mathrm{~min}$ to receive a sucrose pellet, similar to previously published studies (Bari and Pierce, 2005; Hopkins et al, 2012). A between-session, within-subjects design was used to test the effects of VTA amylin receptor activation on sucrose taking. No rank order effects of drug treatment were noted. Each PR test day was separated by 1 day of sucrose self-administration on FR5 to ensure that there were no carryover effects of the previous day's treatment. Once both drug conditions were tested, subjects were mildly food restricted (approximately 90\% of freefeeding BW) in their home cages for the duration of the experiment. Animals self-administered sucrose pellets for 5 days on a FR5 schedule of reinforcement. The effect of intra-VTA sCT on sucrose self-administration on a PR schedule of reinforcement was then tested in the foodrestricted rats. Treatments were again counterbalanced across PR test days and 1 day of sucrose self-administration on FR5 between treatments ensured that sucrose taking had stabilized between test sessions.

\section{Effect of Intra-VTA Amylin Receptor Antagonism on Chow Intake}

One hour before dark onset, food was removed and rats $(n=10)$ were given unilateral VTA injections of the amylin receptor antagonist $\mathrm{AC} 187(0.3 \mu \mathrm{g}$ or $0.17 \mu \mathrm{g})$ or vehicle $(100 \mathrm{nl} \mathrm{aCSF})$. Food was returned at dark onset. Chow intake and BW change were measured at $24 \mathrm{~h}$ post injection.

\section{Dose-Response to IP sCT Administration in Ad Libitum-Fed Rats}

Rats $(n=13)$ received IP injections of sCT $(5 \mu \mathrm{g} / \mathrm{kg}, 3 \mu \mathrm{g} / \mathrm{kg}$, or $1 \mu \mathrm{g} / \mathrm{kg})$ or vehicle $(1 \mathrm{ml} / \mathrm{kg}$ sterile $0.9 \% \mathrm{NaCl})$. Chow intake was measured at $1,3,6$, and $24 \mathrm{~h}$, and $24 \mathrm{~h}$ BW change was also recorded.

Effect of Intra-VTA Amylin Receptor Antagonism on the Intake Suppression Produced by IP sCT Administration

One hour before dark onset, food was removed and rats $(n=7)$ received unilateral VTA injections of AC187 $(0.1 \mu \mathrm{g})$ or its vehicle ( $100 \mathrm{nl}$ aCSF). Just before dark onset, each rat received an IP injection of sCT $(5 \mu \mathrm{g} / \mathrm{kg})$ or its vehicle $(1 \mathrm{ml} / \mathrm{kg} 0.9 \% \mathrm{NaCl})$ and food was returned at dark onset. Chow intake and BW changes were measured at $24 \mathrm{~h}$ post injection.

\section{Data Analysis and Statistics}

Data were analyzed using Statistica (version 7; StatSoft Inc.) and Prism (GraphPad Software). The $\alpha$ level for all tests was set at $P<0.05$. For qPCR studies, data from each site and for each amylin receptor component (CTRs or RAMPs) were run in separate mixed-design ANOVA tests to account for the within-subjects design of the studies. For chow and 15\% sucrose intake studies, as well as open-field analyses, data for each variable (chow, BW, meal size, meal number, sucrose, $\mathrm{kcal}$, total distance) were analyzed using separate mixed-design ANOVA tests to account for the withinsubjects design of the experiments while testing for between-subjects effects of drug treatment(s). Binned data were also analyzed with separate mixed-design ANOVA tests. Statistically significant main effects and interactions were probed using Student-Newman-Keuls post hoc analyses. For operant studies, two-tailed paired $t$-tests were used to analyze each variable in each feeding condition.

\section{RESULTS}

\section{All Components of the Amylin Receptor Complex are Expressed in the VTA}

The amylin receptor complex consists of a CTR (subtypes: A (CTR-A) and B (CTR-B)) heterodimerized with a RAMP (subtypes: RAMP1, RAMP2, and RAMP3; Christopoulos et al, 1999). The different combinations of CTR and RAMP subtypes allow for six possible amylin receptor complexes. Although CTR immunoreactivity is observed in the VTA (Becskei et al, 2004), the identity of the CTR subtype(s) and the presence of RAMP subtypes in this nucleus are unknown. As a preliminary step toward testing a role for VTA amylin receptor signaling in the control of food intake, we used qPCR to identify mRNA expression of the components of the amylin receptor complex in the VTA. In addition, we examined mRNA expression of the two CTR subtypes and the three RAMP subtypes in the NAc core and shell subregions as positive controls, as the NAc expresses amylin receptor complexes consisting primarily of CTR-A and RAMP1 (Oliver et al, 2001; Young, 2005). qPCR analysis revealed that both CTR subtypes and all three RAMP subtypes are expressed in each of the three sites examined, albeit at varying levels of expression. CTR-A mRNA is expressed in VTA, NAc core, and NAc shell at levels higher than that of CTR-B mRNA (Figure 1a-c; ANOVAs, VTA: $\mathrm{F}_{1,9}=6.44, P=0.03$; NAc core: $\mathrm{F}_{1,9}=19.48, P=0.002$; NAc shell: $\mathrm{F}_{1,8}=24.57, P=0.001$; all post hoc analyses, $P<0.05$ ). In both the NAc core and shell, RAMP1 is the most highly expressed RAMP subtype (Figure 1e and f; ANOVAs, NAc core: $F_{2,18}=211.72, P<0.0001 ; \quad N A c$ shell: $F_{2,16}=18.35$, $P=0.0001$; planned comparisons for each site show significantly greater expression of RAMP1 mRNA than other RAMP subtypes $(P<0.05))$. However, mRNA for all three RAMP subtypes is expressed at statistically similar levels in the VTA (Figure 1d; ANOVA: $F_{2,18}=1.65$, $P=0.22$ ). These results suggest that all components of the amylin receptor complex are expressed in the VTA, making it a potentially attractive target for amylin and amylin receptor agonists.

\section{Amylin Receptor Activation in the VTA Reduces Chow Intake by Suppressing Meal Size}

To test the hypothesis that amylin receptor signaling in the VTA controls food intake, ad libitum-fed rats received counterbalanced injections of the amylin receptor agonist sCT (Lutz et al, 2000; 0, 0.004, 0.04, or $0.4 \mu \mathrm{g} / 100 \mathrm{nl} \mathrm{aCSF}$ ) unilaterally into the VTA. A representative image of VTA 
injection placement is shown in Figure 1g. Compared with vehicle treatment, intra-VTA administration of 0.4 or $0.04 \mu \mathrm{g}$ sCT reduced chow intake beginning at $1 \mathrm{~h}$ post injection and persisting throughout the remainder of the $24 \mathrm{~h}$ test (Figure 2a; significant ANOVAs from 1 to $24 \mathrm{~h}$, all $\mathrm{F}_{3,30} \geqslant 4.16, P \leqslant 0.01$; post hoc analyses, 0.4 and $0.04 \mu \mathrm{g}$ different from vehicle $(P<0.05)$ from 1 to $24 \mathrm{~h})$. The $0.004 \mu \mathrm{g}$ dose of sCT had no effect on food intake at any time. Meal pattern analyses revealed that intra-VTA injection of 0.4 or $0.04 \mu \mathrm{g}$ sCT reduced food intake predominantly by reducing meal size, with a significant reduction in meal size beginning $4 \mathrm{~h}$ post injection (Figure 2b; main effect of sCT from 3 to $24 \mathrm{~h}$, all ANOVAs $\left.\mathrm{F}_{3,30} \geqslant 3.02, P \leqslant 0.045\right)$. The meal size-suppressive effect of $0.4 \mu \mathrm{g}$ sCT persisted throughout the remainder of the $24-\mathrm{h}$ test period (post hoc comparison of vehicle vs $0.4 \mu \mathrm{g} s \mathrm{sT}$, $P<0.05$ from 4 to $24 \mathrm{~h}$ ); for $0.04 \mu \mathrm{g} \mathrm{sCT}$, the meal sizesuppressive effect lasted through $6 \mathrm{~h}$ post injection (post hoc comparison of vehicle to $0.04 \mu \mathrm{g}$ sCT, $P<0.05$ from 4 to $6 \mathrm{~h})$. Minor reductions in meal frequency were noted at early times for these doses of sCT (Figure 2c; main effect of sCT at $0.5,1.5$, and $2 \mathrm{~h}$, all ANOVAs $\mathrm{F}_{3,30} \geqslant 3.36, P \leqslant 0.03$ ), but not at later time points when prolonged and robust cumulative food intake suppression by sCT occurred. No effects on meal size or frequency were observed with the $0.004 \mu \mathrm{g}$ dose of $\mathrm{sCT}$. BW gain over the 24 -h test was reduced by $0.4 \mu \mathrm{g}$ sCT (mean $\mathrm{BW}$ change $(\mathrm{g}) \pm \mathrm{SEM}: 0 \mu \mathrm{g}$, $2.64 \pm 1.73 ; 0.004 \mu \mathrm{g}, 4.98 \pm 2.03 ; 0.04 \mu \mathrm{g}, 4.24 \pm 1.48 ; 0.4 \mu \mathrm{g}$, $-4.98 \pm 4.45$; ANOVA: $\mathrm{F}_{3,30}=3.52, P=0.03$; post hoc comparison, $0.4 \mu \mathrm{g}$ sCT different from all other doses $(P<0.05))$. Taken together, these results indicate that intraVTA sCT reduces chow intake primarily by suppressing meal size with minimal changes to meal frequency, suggesting that VTA amylin receptor signaling may be reducing the rewarding value of the ongoing meal.

To ensure that the doses of sCT selected for parenchymal injection in the VTA were subthreshold for effect when delivered to the cerebroventricular system, we tested the food intake-suppressive effects of the same doses of sCT when delivered to the third cerebroventricle (3rd ICV). The $0.4 \mu \mathrm{g}$ dose of sCT administered 3rd ICV potently suppressed food intake at all time points examined (Figure 2d; significant ANOVAs from 1 to $24 \mathrm{~h}$, all $\mathrm{F}_{3,39} \geqslant 9.24, P \leqslant 0.0001$; vehicle vs $0.4 \mu \mathrm{g}$ sCT significant $(P<0.05)$ at all times $)$ and robustly reduced $24 \mathrm{~h} \mathrm{BW}$ gain (mean BW change (g士SEM: $0 \mu \mathrm{g}, 0.01 \pm 1.35 ; 0.004 \mu \mathrm{g}$, $-4.35 \pm 2.31 ; 0.04 \mu \mathrm{g},-0.64 \pm 2.25 ; 0.4 \mu \mathrm{g},-33.20 \pm 2.86$; ANOVA: $\mathrm{F}_{3,39}=46.83, P<0.0001$; vehicle $v s 0.4 \mu \mathrm{g} \mathrm{sCT}$, $P<0.05$ ). However, $0.04 \mu \mathrm{g}$ sCT (3rd ICV) had only a transient effect on food intake at $1 \mathrm{~h}$ post injection compared with vehicle-treated rats $(P<0.05)$, with no effects on food intake at later time points over the $24-\mathrm{h}$

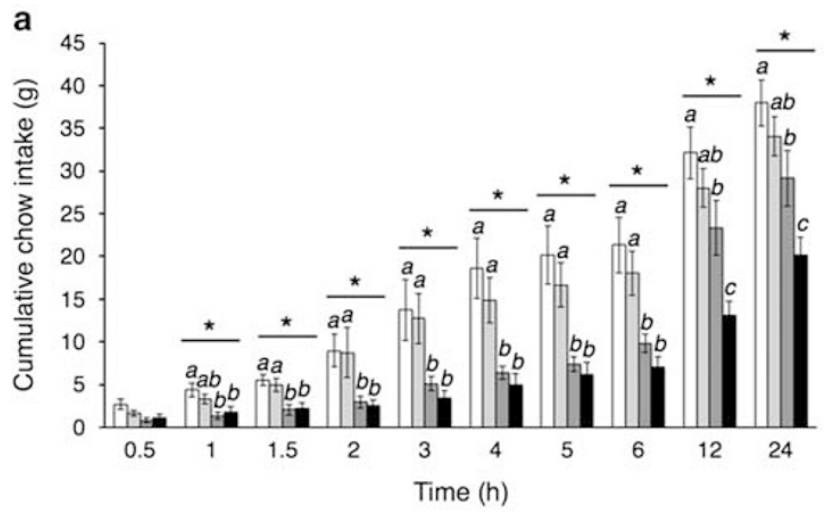

C

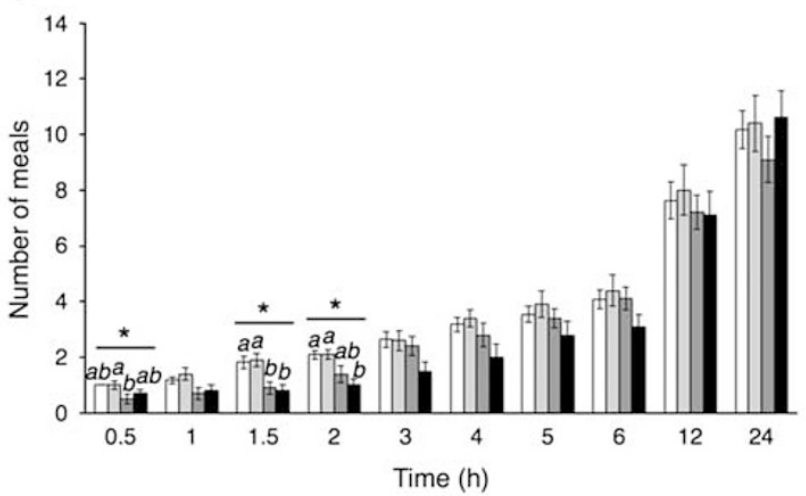

Vehicle b

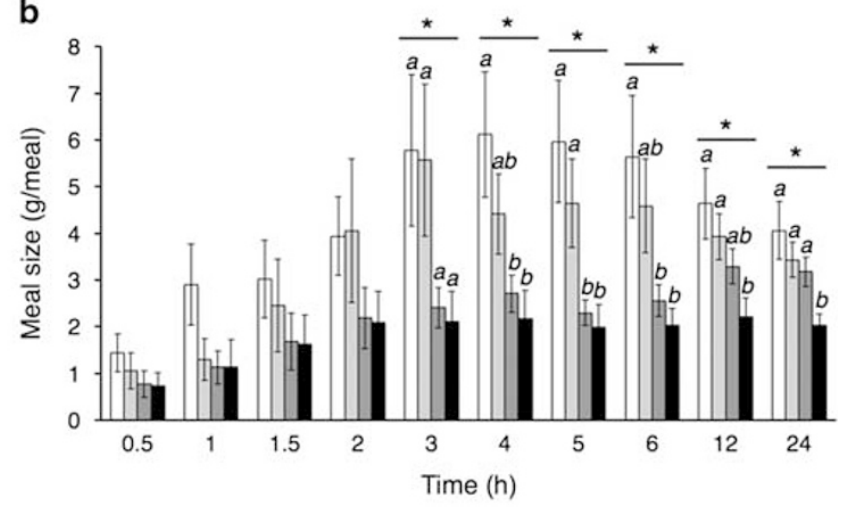

d

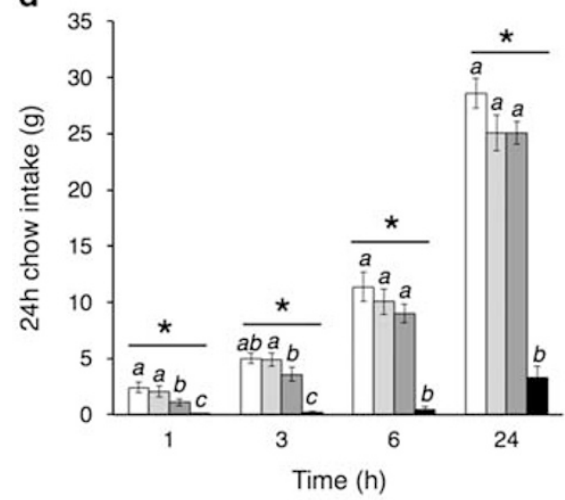

$0.4 \mu \mathrm{g} \mathrm{sCT}$

Figure 2 Amylin receptor activation in the VTA reduces chow intake primarily by decreasing meal size. VTA administration of the amylin receptor agonist sCT $(n=1 \mathrm{I})$ reduced cumulative chow intake (a) and meal size (b) with only minor early effects on meal frequency (c). When the same doses of sCT were delivered into the $3 r d$ cerebroventricle $(n=14)$, only the highest dose of $\mathrm{sCT}$ had prolonged effects on food intake (d). *Main effect of sCT (P<0.05); within time bin, bars with different letters are significantly different from each other $(P<0.05)$. All data shown as mean \pm SEM. 
period of recording and no effect on $24 \mathrm{~h}$ BW gain. The minimal transient effect for the $0.04 \mu \mathrm{g}$ dose of $\mathrm{sCT}$ when given 3rd ICV contrasts with the prolonged and potent anorectic effects of this dose when administered directly into the VTA, suggesting that $0.04 \mu \mathrm{g} \mathrm{sCT}$ is subthreshold in the ventricle for prolonged effects on food intake. The lowest dose of sCT tested, $0.004 \mu \mathrm{g}$, had no significant effect on food intake or $24 \mathrm{~h} \mathrm{BW}$ when given 3rd ICV $(P>0.05)$.

\section{Amylin Receptor Activation in the VTA Suppresses Food Intake without Inducing Nausea/Malaise or Suppressing Locomotor Activity}

To determine whether nausea/malaise contributes to the food intake-suppressive effects produced by VTA amylin receptor signaling, we availed of an established model of nausea/malaise (Alhadeff et al, 2012; Andrews and Horn, 2006; De Jonghe and Horn, 2008; Kanoski et al, 2012; Mitchell et al, 1976) by examining pica, the consumption of a non-nutritive substance (eg, kaolin silicate clay). Rats received counterbalanced intra-VTA injections of sCT $(0$, $0.004,0.04$, or $0.4 \mu \mathrm{g} / 100 \mathrm{nl} \mathrm{aCSF}$ ) and intake of chow and kaolin were measured for $24 \mathrm{~h}$. As in our previous experiment, the two highest doses of sCT tested ( 0.4 and $0.04 \mu \mathrm{g}$ ) reduced $24 \mathrm{~h}$ chow intake (Figure 3a; ANOVA: $\mathrm{F}_{3,18}=7.34, P=0.002$; vehicle $v s 0.04$ or $\left.0.4 \mu \mathrm{g}, P<0.05\right)$ and $0.4 \mu \mathrm{g}$ sCT reduced $24 \mathrm{~h}$ BW gain (Figure 3c; ANOVA: $\mathrm{F}_{3,18}=3.38, P=0.04$; vehicle vs $\left.0.4 \mu \mathrm{g}, P<0.05\right)$. However, intra-VTA sCT administration did not cause rats to ingest kaolin clay (Figure 3b; ANOVA: $F_{3,18}=0.66, P=0.59$ ), indicating that intra-VTA amylin receptor activation reduces food intake without producing nausea/malaise.

In a separate group of rats, we tested whether suppression of locomotor activity by VTA amylin receptor activation could explain the observed reductions in food intake produced by intra-VTA sCT administration. Rats were placed in open-field chambers and total distance traveled (inches) was measured. No differences in pre-drug total distance were observed (Figure $3 \mathrm{~d}$ and e; ANOVA for $30 \mathrm{~min}$ average: $\mathrm{F}_{2,16}=1.34, P=0.29$ ). However, in rats given an intra-VTA injection of sCT $(0.04 \mu \mathrm{g})$, a transient suppressive effect on locomotor activity was observed from 30 to 60 min post injection (Figure 3e; ANOVA: $F_{2,16}=5.60$, $P=0.01$; vehicle $v s$ sCT, $P<0.05)$, with no significant differences observed at later times (all ANOVAs: $\mathrm{F}_{2,16} \leqslant 1.84$, all $\left.P \geqslant 0.19\right)$. Rats given an intra-VTA injection of the amylin receptor antagonist AC187 $(0.3 \mu \mathrm{g})$ displayed a brief enhancement of locomotor activity at $70 \mathrm{~min}$ post injection (Figure 3d; ANOVA: $F_{2,16}=3.85, P=0.04$; vehicle vs AC187, $P<0.05)$ but no significant effects of AC187 were observed in the $30 \mathrm{~min}$ bins (Figure $3 \mathrm{e}$ ). Given that intraVTA sCT reduces food intake throughout a 24 -h period, these results suggest that although suppression of locomotor activity may contribute to the very early anorectic effects of the drug (ie, within the first $60 \mathrm{~min}$ post injection), the majority of the intake-suppressive effects of VTA amylin receptor activation are not due to alterations in locomotor activity.
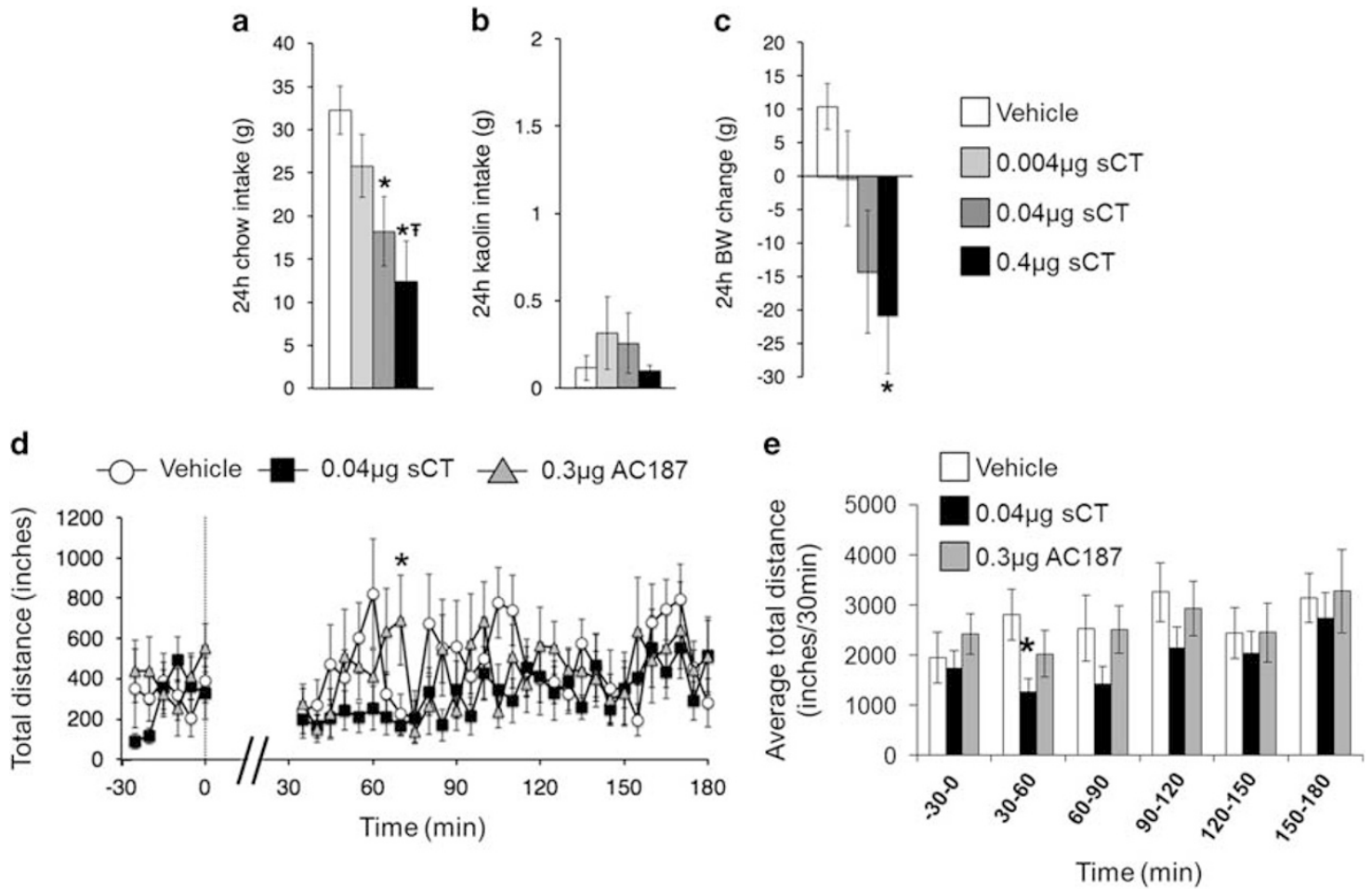

Figure 3 VTA amylin receptor activation reduces food intake without inducing nausea or suppressing locomotor activity. Intra-VTA sCT injection suppressed chow intake (a) and body weight (c) but did not induce kaolin ingestion (b) $\left(n=7\right.$; * different from $0 \mu \mathrm{g}(P<0.05)$; ${ }^{\mp}$ different from $0.004 \mu \mathrm{g}$ $(P<0.05))$. The key next to panel $\mathrm{c}$ applies to panels a-c. In a separate group of rats, intra-VTA amylin receptor activation with sCT transiently reduced total distance traveled in an open-field chamber, whereas intra-VTA administration of the amylin receptor antagonist ACI 87 transiently increased total distance traveled $(d, e)(n=9$; *different from vehicle $(P<0.05))$. Data from 5 min bins are shown in d, with vertical dashed line indicating time of intra-VTA drug administration. Average total distance for each $30 \mathrm{~min}$ bin is depicted in e. All data shown as mean $\pm \mathrm{SEM}$. 
VTA Amylin Receptor Activation Reduces Intake of Palatable Sucrose Solution

The VTA and other structures in the mesolimbic dopamine system are important for the control of palatable food intake and food reward (Narayanan et al, 2010; Vucetic and Reyes, 2010). To investigate whether VTA amylin receptor signaling controls palatable food intake, rats habituated to a 1 -h access to $15 \%$ sucrose solution received counterbalanced intra-VTA injections of sCT $(0.04$ or $0.01 \mu \mathrm{g})$ or vehicle ( $100 \mathrm{nl} \mathrm{aCSF})$ just before sucrose presentation and intake was recorded every $10 \mathrm{~min}$ for $1 \mathrm{~h}$. The doses of sCT selected were suprathreshold $(0.04 \mu \mathrm{g}$; see Figure $2 \mathrm{a})$ or subthreshold ( $0.01 \mu \mathrm{g}$; data not shown) for an effect on $1 \mathrm{~h}$ chow intake when delivered to the VTA. Both doses of SCT significantly reduced sucrose intake (Figure 4a; main effect of $\mathrm{sCT}$ at 40 and $60 \mathrm{~min}$; ANOVAs $\mathrm{F}_{2,28} \geqslant 3.59, P \leqslant 0.04$; vehicle vs $0.04 \mu \mathrm{g} \mathrm{sCT}$ significant $(P<0.05)$ at both times, vehicle $v s 0.01 \mu \mathrm{g}$ sCT significant $(P<0.05)$ at $60 \mathrm{~min})$. After the sucrose access period, chow was returned and $23 \mathrm{~h}$ chow intake was measured. The $0.04 \mu \mathrm{g}$ dose of sCT reduced $23 \mathrm{~h}$ chow intake, but $0.01 \mu \mathrm{g}$ sCT had no effect on chow intake in contrast to the suppression produced for sucrose intake (Figure 4b; ANOVA: $\mathrm{F}_{2,28}=4.97, P=0.01$; post hoc comparison of vehicle $v s 0.04 \mu \mathrm{g} \mathrm{sCT}, P<0.05)$. Total $24 \mathrm{~h}$ energy intake (kcal from sucrose + chow) was significantly reduced after administration of $0.04 \mu \mathrm{g}$ sCT (Figure 4c; ANOVA: $\mathrm{F}_{2,28}=5.62, P=0.01$; post hoc comparison of vehicle $v s$ $0.04 \mu \mathrm{g} \mathrm{sCT}, P<0.05)$. Finally, $24 \mathrm{~h} \mathrm{BW}$ change was reduced by $0.04 \mu \mathrm{g}$ sCT (Figure $4 \mathrm{~d}$; ANOVA: $\mathrm{F}_{2,28}=5.39, P=0.01$; post hoc comparison of vehicle $v s 0.04 \mu \mathrm{g}$ sCT, $P<0.05$ ). These results indicate that VTA amylin receptor signaling reduces intake of not only chow but also a palatable food.

\section{VTA Amylin Receptor Activation Decreases Sucrose Self-Administration in Food-Restricted Rats, as well as Ad Libitum-Fed Rats}

To test whether VTA amylin receptor signaling mediates motivation to obtain a palatable food, rats were infused with sCT $(0.04 \mu \mathrm{g})$ or vehicle $(100 \mathrm{nl} \mathrm{aCSF})$ directly into the VTA and were immediately placed in operant chambers and allowed to lever press for sucrose pellets on a PR schedule of reinforcement. Initially, animals were tested in an ad libitum-fed state. Paired $t$-tests revealed that, compared with vehicle treatment, intra-VTA sCT reduced active lever responding $(t(9)=2.64 ; P<0.05)$, total sucrose pellets selfadministered $(t(9)=2.60 ; \quad P<0.05)$, and break points $(t(9)=2.65 ; \quad P<0.05)$ compared with vehicle treatment (Figure 5a-c).

After the first series of PR test sessions, rats were mildly food-restricted (approximately 90\% of free-feeding BW) and allowed to self-administer sucrose pellets on an FR5 schedule of reinforcement. Once sucrose self-administration behavior had stabilized, the now food-restricted rats received intra-VTA infusions of vehicle $(100 \mathrm{nl} \mathrm{aCSF})$ or sCT $(0.04 \mu \mathrm{g})$ immediately before a PR test session. Similar to the effects observed under ad libitum-fed conditions, $\mathrm{sCT}$ reduced active lever responding $(t(9)=3.50 ; P<0.05)$, total sucrose pellets self-administered $(t(9)=4.38 ; P<0.05)$, and break points $(t(9)=3.22 ; P<0.05)$ compared with vehicle treatment (Figure $5 \mathrm{~d}-\mathrm{f}$ ). Together, these data demonstrate

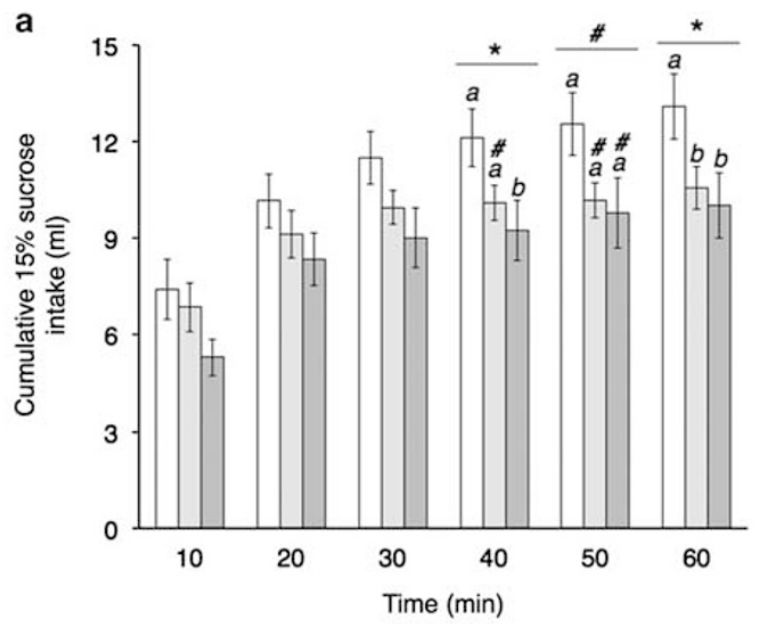

b

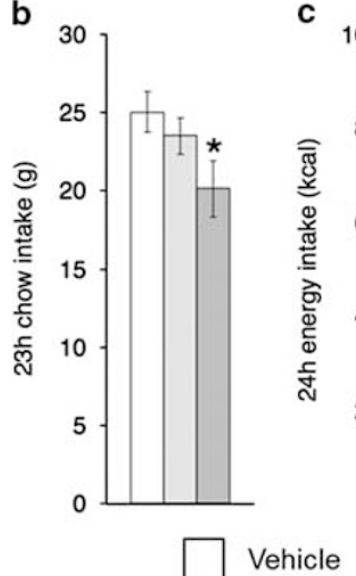

100

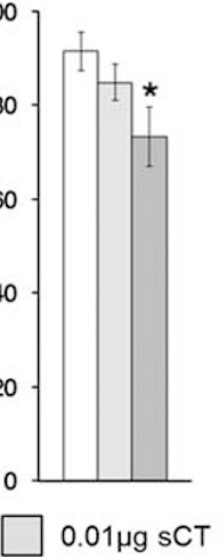

d

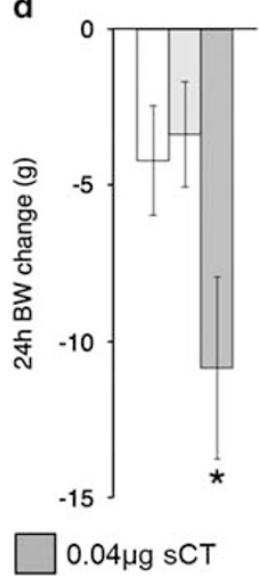

Figure 4 VTA amylin receptor activation suppresses intake of a palatable sucrose solution. Rats $(n=15)$ that received SCT into the VTA reduced intake of I5\% sucrose during a I h sucrose access period (a) (*main effect of sCT $(P<0.05)$; \#statistical trend of sCT compared with vehicle $(P<0.08)$; within time bin, bars with different letters are significantly different from each other $(P<0.05))$. Subsequent chow intake $(b)$, total $24 \mathrm{~h}$ energy intake (c), and $24 \mathrm{~h}$ body weight change (d) were also reduced by $\mathrm{sCT}$, but only by the higher $(0.04 \mu \mathrm{g})$ dose of drug (*significantly different from vehicle $(P<0.05))$. All data shown as mean \pm SEM.

that intra-VTA amylin receptor activation reduces the motivation to obtain a palatable food reward in both ad libitum-fed and food-restricted rats.

\section{Amylin Receptor Signaling in the VTA is Physiologically and Potentially Clinically Relevant to Food Intake Control}

Although agonist studies are informative, the physiological relevance of endogenous VTA amylin signaling to the control of food intake remains unknown. To address this issue, rats received counterbalanced intra-VTA injections of the amylin receptor antagonist AC187 (Mollet et al, 2004; Rushing et al, 2001; 0.3 or $0.17 \mu \mathrm{g})$ or vehicle ( $100 \mathrm{nl} \mathrm{aCSF})$ and $24 \mathrm{~h}$ chow intake and BW change were measured. Blockade of VTA amylin receptors by AC187 significantly increased $24 \mathrm{~h}$ chow intake (Figure 6a; ANOVA: $\mathrm{F}_{2,18}=8.43, P=0.003$; vehicle $v s 0.17$ or $0.3 \mu \mathrm{g}, P<0.05$ ) and produced a nonsignificant increase in $\mathrm{BW}$ gain 

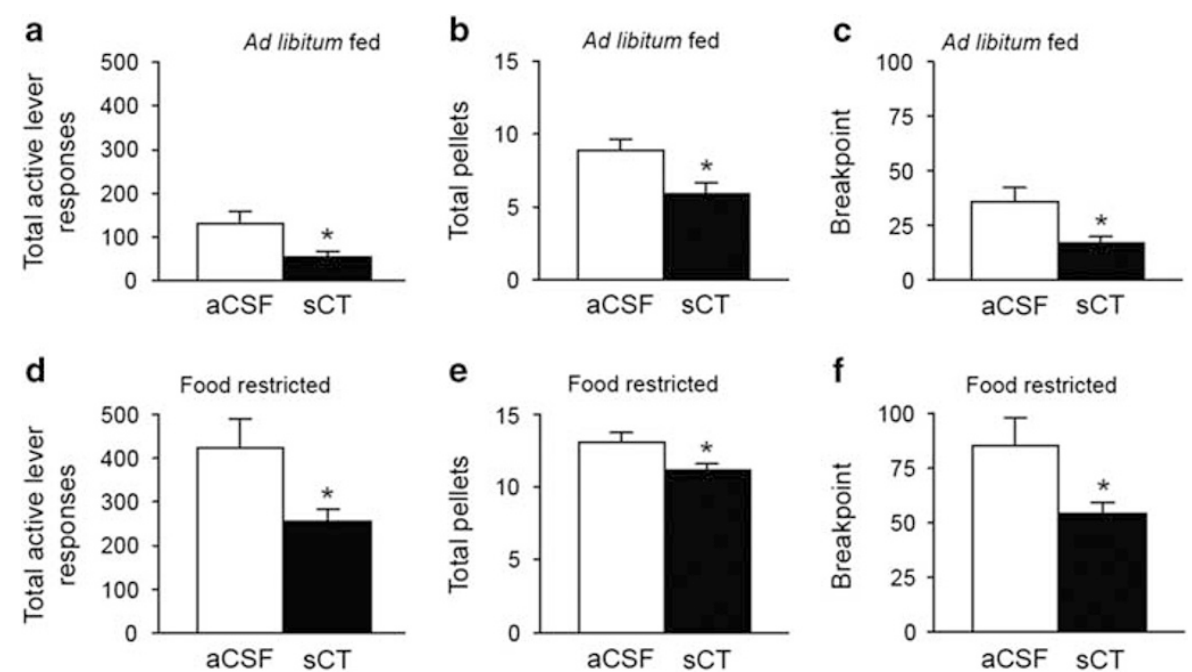

Figure 5 Administration of salmon calcitonin ( $\mathrm{SCT}$ ) directly into the VTA attenuates sucrose self-administration in ad libitum-fed as well as food-restricted rats. Intra-VTA pretreatment with sCT reduced total active lever responses (a, d), total sucrose pellets self-administered (b, e), and break points (c, $f$ ) in both ad libitum-fed $(\mathrm{a}-\mathrm{c})$ and food-restricted rats $(\mathrm{d}-\mathrm{f})$ self-administering sucrose pellets on a PR schedule of reinforcement $(n=10$ per feeding condition). *Significant difference from vehicle (paired t-test, $P<0.05$ ). All data shown as mean $\pm \mathrm{SEM}$.

(Figure 6b; ANOVA: $\mathrm{F}_{2,18}=1.77, P=0.2$ ). Thus, endogenous amylin receptor signaling in the VTA is physiologically relevant for the control of food intake.

Given that endogenous amylin (putatively from pancreatic $\beta$-cells; Johnson et al, 1988; Kahn et al, 1990) acts at VTA amylin receptors to control food intake, this raises the intriguing possibility that systemically administered amylin receptor agonists (mimicking the clinical route of administration in humans for the treatment of diabetes), may reduce food intake and BW by direct action on VTA amylin receptors. To test this hypothesis, we first examined the food intake-suppressive effect of a peripherally administered amylin agonist (sCT; $0,0.5,1$, or $5 \mu \mathrm{g} / \mathrm{kg}$ ) in ad libitum-fed rats, as to date, the majority of research has examined these effects in food-restricted rats (Lutz et al, 2000). Only the highest IP dose of sCT tested, $5 \mu \mathrm{g} / \mathrm{kg}$, significantly reduced food intake throughout the entire 24 -h test period (Figure 6c; main effect of sCT from 1 to $24 \mathrm{~h}$, all ANOVAs $\mathrm{F}_{3,36} \geqslant 3.07, P \leqslant 0.04$; post hoc comparisons between vehicle and $5 \mu \mathrm{g} / \mathrm{kg} \mathrm{sCT}, P<0.05$ at all times) and also reduced $24 \mathrm{~h}$ BW gain (Figure 6d; ANOVA: $\mathrm{F}_{3,36}=8.38$, $P=0.0002$; post hoc comparisons between vehicle and $5 \mu \mathrm{g} / \mathrm{kg}$ sCT, $P<0.05)$. Next, in separate rats we tested whether blockade of VTA amylin receptors by AC187 $(0.1 \mu \mathrm{g})$ can attenuate the intake-suppressive effects of peripherally administered sCT $(5 \mu \mathrm{g} / \mathrm{kg})$. The dose of AC187 used in this study is lower than the doses used in the previous study, and thus had no effect on chow intake on its own. The results of this cross-site study revealed that VTA amylin receptors directly mediate the food intake-suppressive effects of a systemically administered amylin receptor agonist, as blockade of VTA amylin receptors by intraVTA administration of AC187 attenuated the IP sCTinduced suppression in food intake (Figure 6e; main effect of sCT, ANOVA: $\mathrm{F}_{1,6}=30.08, P=0.002$; planned comparison between vehicle/sCT and AC187/sCT, $P<0.05)$ and $\mathrm{BW}$ (Figure 6f; main effect of AC187, $\mathrm{F}_{1,6}=10.51, P=0.02$; main effect of sCT, $\mathrm{F}_{1,6}=12.79, P=0.01$; planned comparison between vehicle/sCT and AC187/sCT, $P<0.05)$. These data provide support for the notion that the VTA may be a clinically relevant site of action that directly mediates the intake-suppressive effects of peripherally administered amylin receptor agonists.

\section{DISCUSSION}

The control of food intake by amylin receptor signaling in nuclei other than the AP and hypothalamus has largely been under-investigated, despite evidence indicating that amylin readily crosses the blood-brain barrier and binds to numerous sites throughout the neuraxis (Beaumont et al, 1993; Christopoulos et al, 1995; Paxinos et al, 2004; Sexton et al, 1994). The present studies provide the first evidence that endogenous and exogenous amylin receptor signaling in the VTA control for food intake, making VTA amylin receptor signaling not only physiologically relevant for the control of energy balance, but also perhaps clinically relevant for the treatment of obesity.

Using the amylin receptor agonist sCT, current data demonstrate that activation of amylin receptors specifically in the VTA reduces chow intake in ad libitum-fed rats. Meal pattern analyses revealed that this effect was mainly due to suppression of meal size, rather than changes to meal frequency, an effect that is consistent with the mechanism of intake suppression produced by peripherally administered amylin receptor agonists (Bello et al, 2008; Lutz et al, 1995b). Thus, it is logical that VTA amylin receptor signaling may control for food intake by modulating the rewarding value of the ongoing meal while having fewer effects on satiety (inter-meal processes). Notably, this anorectic effect was not due to induction of nausea/malaise, as intra-VTA SCT reduced chow intake without producing a pica response. In addition, although intra-VTA sCT injection induced a transient reduction in locomotor activity at $30-60 \mathrm{~min}$ post injection, this does not appear 
a $\begin{aligned} & \text { Intra-VTA } \\ \square & \text { aCSF } \\ \square & 0.17 \mu \mathrm{g} \mathrm{AC} 187 \\ \square & 0.3 \mu \mathrm{g} \mathrm{AC} 187\end{aligned}$

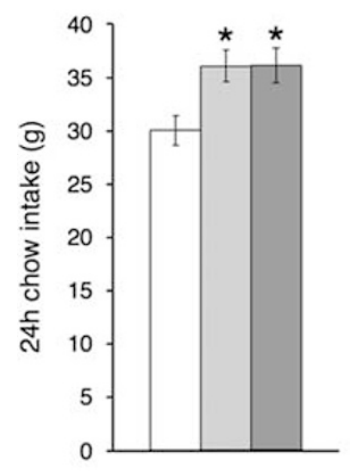

b

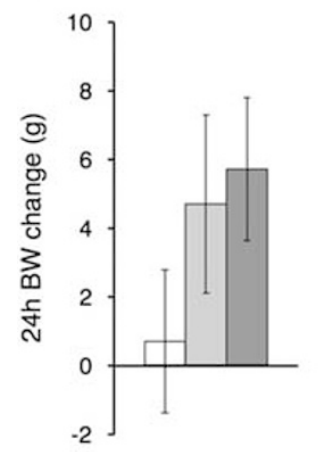

C Intraperitoneal $\square$ aCsF $\square 0.5 \mu \mathrm{g} / \mathrm{kg} \mathrm{sCT}$ $1 \mu \mathrm{g} / \mathrm{kg} \mathrm{sCT}$

$5 \mu \mathrm{g} / \mathrm{kg} \mathrm{sCT}$

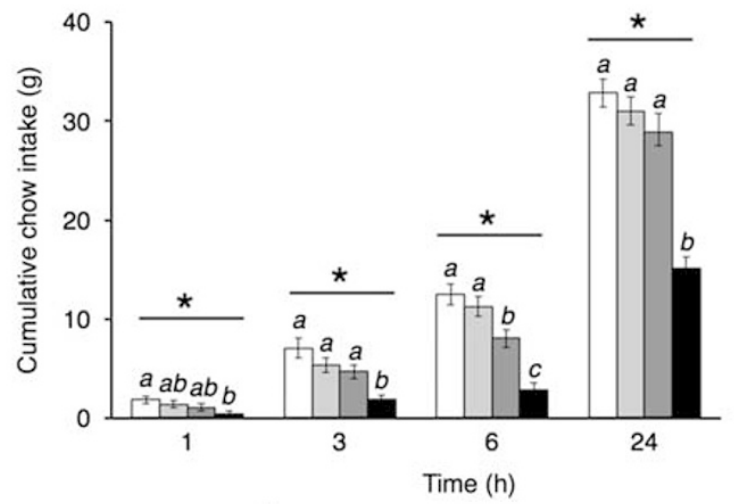

d

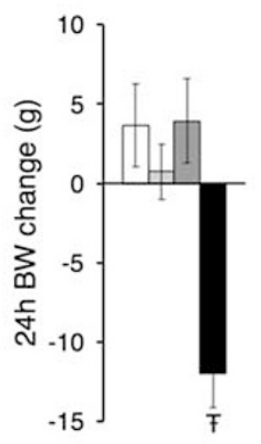

e

Intra-VTAAC187+ IP SCT

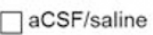

AC187 $(0.1 \mu \mathrm{g}) / \mathrm{saline}$ $\mathrm{aCSF} / \mathrm{sCT}(5 \mu \mathrm{g} / \mathrm{kg})$

$\square \mathrm{AC} 187(0.1 \mu \mathrm{g}) / \mathrm{sCT}(5 \mu \mathrm{g} / \mathrm{kg})$

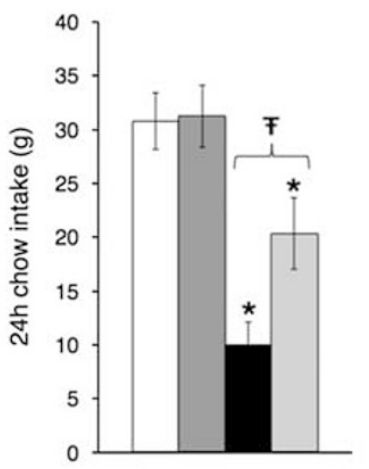

f

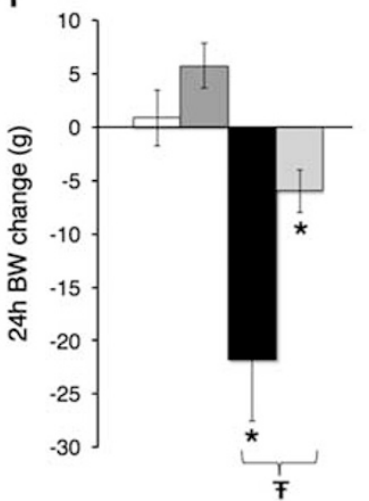

Figure 6 VTA amylin receptor blockade increases food intake and attenuates the suppression of chow intake produced by a peripherally administered amylin receptor agonist. Rats that received an intra-VTA injection of the amylin receptor antagonist ACI $87(0.17$ or $0.3 \mu \mathrm{g})$ significantly increased $24 \mathrm{~h}$ chow intake (a) and showed a nonsignificant increase in body weight (b) $(n=10$; *different from vehicle $(P<0.05))$. In a separate cohort of animals, a doseresponse study of the effects of IP sCT on food intake and body weight gain in ad libitum-fed rats demonstrated that the highest dose of sCT tested (5 $\mu \mathrm{g} / \mathrm{kg}$ ) potently suppressed food intake (c) and body weight gain (d) $(n=13$; *main effect of sCT $(P<0.05)$; within time bin, bars with different letters are significantly different from each other $(P<0.05)$. ${ }^{\mp}$ Post hoc comparison indicates significant difference from all other treatments $(P<0.05)$ after significant overall ANOVA $(P<0.05)$ ). Finally, in a third group of rats, intra-VTA pretreatment with ACI $87(0.1 \mu$ g; dose selected to have no effect on $24 \mathrm{~h}$ chow intake on its own) attenuated the food intake- (e) and body weight-suppressive ( $f$ ) effects of $5 \mu \mathrm{g} / \mathrm{kg}$ IP sCT administration ( $n=7$; *different from aCSF/sal $(P<0.05)$; ${ }^{7}$ difference between aCSF/sCT and ACI87/sCT $\left.(P<0.05)\right)$. All data shown as mean \pm SEM.

to be a primary mechanism by which VTA amylin receptor activation reduces food intake, because the intake-suppressive effects of intra-VTA sCT last far longer $(24 \mathrm{~h})$ than the effects on locomotor activity.

As neuronal processing by the VTA is well known to affect palatable food intake (Egecioglu et al, 2011; Vucetic and Reyes, 2010), it is notable that intra-VTA amylin receptor activation not only reduced intake of standard rodent chow, but also reduced intake of a palatable sucrose solution with an extremely low dose of sCT that had no effect on chow intake following VTA delivery. Collectively, the current results show that activation of VTA amylin receptors controls food intake by influencing meal sizespecific processing. It is worth noting that the doses of sCT selected for this study were based in part on a previous report indicating that intra-AP administration of $0.4 \mu \mathrm{g} \mathrm{sCT}$ reduced $1 \mathrm{~h}$, but not 2 or $4 \mathrm{~h}$, food intake in rats (Mollet et al, 2004). In the present studies, not only did intra-VTA administration of this same dose of $\mathrm{sCT}$ potently reduce food intake for at least $24 \mathrm{~h}$, but also intra-VTA administration of $\mathrm{sCT}$ at doses far lower $(0.01$ and $0.04 \mu \mathrm{g})$ also reduced chow intake and sucrose intake. These data further indicate that the control of food intake by the amylin system is not restricted to action in the AP, but also involves processing by the VTA.

It is worth noting that the binding association between sCT and amylin receptors is reported to be more longlasting than binding of native amylin to the amylin receptor (Christopoulos et al, 1999; Lutz et al, 2000). However, a major discovery from the current studies is the finding that VTA amylin receptors are also a physiologically relevant site of action for food intake control by endogenous amylin, as blockade of VTA amylin receptors by the antagonist AC187 increased food intake. Interestingly, intra-VTA AC187 had only a very brief, transient effect on locomotor activity. Given that intra-VTA sCT also had only minimal 
and transient effects on locomotor activity, it appears that changes in VTA amylin receptor activity selectively alter feeding and have relatively little impact on locomotor function.

An additional noteworthy finding of the current studies is the fact that selective blockade of VTA amylin receptors by AC187 attenuated the intake-suppressive effects of a peripherally administered amylin receptor agonist. Given that amylin can penetrate the blood-brain barrier (Banks et al, 1995), gaining direct access to distributed CNS nuclei controlling for energy balance, this raises the intriguing possibility that the VTA may also be a clinically relevant site mediating the food intake- and BW-suppressive effects of systemically administered amylin analogs. Indeed, amylin analogs are already used clinically to treat diabetes mellitus (Singh-Franco et al, 2007) and have the additional effects of reducing food intake, BW, and appetite in humans (Chapman et al, 2007; Smith et al, 2007). Current results should therefore broaden the understanding of the behavioral and neuronal mechanisms that mediate the aforementioned clinical findings and also promote future imaging research examining neural activation in the mesolimbic reward system (specifically the VTA) of humans receiving amylin analogs for diabetes/obesity treatment.

Previous studies demonstrating binding of amylin and sCT in the VTA (Beaumont et al, 1993; Christopoulos et al, 1995; Paxinos et al, 2004; Sexton et al, 1994) provided initial supporting evidence for the VTA as a potential amylinresponsive site. The current $\mathrm{qPCR}$ results provide quantifiable data that support this idea, as mRNA for all components of the amylin receptor complex are expressed within the VTA, including both subtypes of CTR and all three RAMP subtypes. Although further investigation is needed to identify the phenotype(s) of VTA neurons (eg, dopaminergic, GABAergic, glutamatergic) that express the amylin receptor complex, the equivalent expression of the three RAMP subtypes within the VTA contrasts with the prevalence of RAMP1 mRNA expression in the NAc (Oliver et al, 2001), as well as with the prevalence of RAMP2 and RAMP3 in the AP (Barth et al, 2004). Different combinations of RAMP and CTR subtypes create receptor complexes that all bind amylin but also have differing affinities for other calcitonin family ligands such as calcitonin generelated peptide and adrenomedullin. Worth noting is the fact that RAMP2 and RAMP3 may confer additional specificity for amylin binding (Christopoulos et al, 1999). Therefore, given that all RAMP subtypes are equally expressed in the VTA, compared with a more selective expression of RAMP1 in the NAc, amylin receptor complexes within the VTA may respond more preferentially and specifically to amylin analogs than do NAc amylin receptors. This may explain why NAc amylin receptor signaling does not control for food intake (Baldo and Kelley, 2001), whereas current data provide convincing evidence that VTA amylin receptor signaling is physiologically and pharmacologically relevant for the control of food intake.

The VTA has been recognized as an important nucleus in the control of food intake, especially palatable food intake (Narayanan et al, 2010; Vucetic and Reyes, 2010), as well as in the broader context of motivated appetitive behaviors (eg, drug taking/seeking; Schmidt et al, 2009; Self, 2004). The finding that intra-VTA amylin receptor activation reduces intake of standard chow and palatable sucrose solution, as well as self-administered sucrose pellets, offers the intriguing possibility that amylin receptor activation in the VTA may reduce motivation to obtain food. Indeed, intra-VTA SCT reduced parameters of sucrose self-administration in ad libitum-fed and food-restricted rats, suggesting that VTA amylin receptor signaling decreases motivation to obtain a palatable sucrose reward. Interestingly, the ability of sCT to reduce operant responding for sucrose pellets was attenuated in food-restricted rats compared with ad libitum-fed animals (per cent suppression produced by sCT in ad libitum-fed $v s$ food-restricted rats, respectively: active lever presses, $44 \%$ vs $34 \%$; pellets earned, $28 \%$ vs $14 \%$; break point, $38 \%$ vs $31 \%$ ). These slight differences may be due to the additional motivation to obtain food produced by chronic food deprivation. Together, these findings suggest that VTA amylin receptor activation may reduce food-directed motivational processes. Whether VTA amylin receptor signaling contributes to the expression of other non-food-oriented appetitive behaviors is an interesting hypothesis that requires further investigation.

Until now, the AP has been viewed as the primary site of action for the intake-suppressive effects of amylin. Numerous papers clearly establish the AP as an important amylinresponsive site (Lutz et al, 2000, 2001; Mollet et al, 2004; Potes et al, 2010; Riediger et al, 2002), especially for shortterm effects on food intake (Lutz et al, 1994, 1995b). Indeed, AP lesions (Lutz et al, 1998, 2001) and intra-AP amylin receptor antagonist administration (Mollet et al, 2004) have provided data that establish the AP as a physiologically relevant site of action for amylin-mediated effects on food intake. Importantly, however, the results of these aforementioned studies should not be interpreted to indicate that the AP is the only CNS structure mediating the intakesuppressive effects of amylin signaling. Moreover, given that an AP-lesioned rat is a compromised animal that exhibits persistent daily reductions in food intake and BW compared with sham-operated controls (Lutz et al, 1998), and that the dose of the amylin receptor antagonist, AC187, used in the previous AP reports is 100-fold higher (Mollet et al, 2004) than the highest dose of the same drug used in the present studies, some caution should be used when interpreting the requirement of the AP in mediating all of the intake-regulatory effects of amylin signaling. Another important consideration is that most of the previous reports examining amylin's actions in the AP test the effects of amylin receptor activation in food-restricted animals (Lutz et al, 1995a, 1995b, 1998, 2000) and report short-term effects on food intake (Lutz et al, 1995a, 1995b; Reidelberger et al, 2004). In the present studies, we have examined cumulative food intake effects at short and long time periods (up to $24 \mathrm{~h}$ ) in ad libitum-fed rats, thus providing analyses of the intake-inhibitory effects of VTA amylin signaling in an animal with natural feeding rhythms. By no means are these limitations pointed out to dismiss the overwhelming evidence in the literature that validates the importance of the AP as a physiologically relevant site of action for amylin-mediated effects on feeding. Rather, these points are made to highlight the fact that, as research and reviews have focused on the AP as the primary site of action for amylin, the possible contribution of neural processing by other 
nuclei in mediating the anorectic effects of amylin signaling has been largely overlooked. Indeed, the present results indicate that investigation of other potential amylinresponsive nuclei is both warranted and necessary to fully understand the intake- and BW-suppressive actions of this neuropeptide system.

The mechanism by which VTA amylin receptor activation reduces food intake remains an open question. Although the cellular/neuronal mechanisms mediating the intakesuppressive effects of amylin receptor signaling are beginning to be elucidated, studies have focused mainly on the AP. For example, amylin excites AP neurons (Riediger et al, 2001), likely through a glutamatergic mechanism (Fukuda et al, 2013). Within the AP, the extracellular signalregulated kinase $1 / 2$ pathway is important for the anorectic effects of amylin (Potes et al, 2012), and norepinephrine neurons partially mediate these effects as well (Potes et al, 2010). Other central neurotransmitter systems including histamine are implicated in the intake-suppressive effects of peripherally administered amylin (Lutz et al, 1996; Mollet et al, 2001, 2003; Seth et al, 2012). In contrast to the reports that have examined amylin action in the AP, the intracellular signaling mechanisms mediating the food intakesuppressive effects of amylin receptor activation in other brain regions are largely unknown. Although it is certainly possible that at least some of the known mechanisms that mediate amylin receptor signaling in the AP are recapitulated in the VTA, the present data indicate that VTA amylin receptors may differ from amylin receptor populations in other sites in a way that may be functionally meaningful. Specifically, all three RAMPs are expressed in similar levels within the VTA, compared with other sites such as the NAc and the AP (Young, 2005) where one RAMP subtype prevails. Indeed, differences in intracellular or intercellular signaling pathways engaged by AP vs VTA amylin receptor populations may help to explain the disparate time courses of feeding effects obtained after AP $v s$ VTA amylin receptor activation (Mollet et al, 2004); this is an intriguing possibility that should be tested empirically. Given the important role of mesolimbic dopamine signaling in the regulation of feeding (Narayanan et al, 2010; Vucetic and Reyes, 2010), VTA amylin-induced alterations in dopamine production or release may also mediate the feeding effects observed in the present studies, but this too remains to be examined.

The current results demonstrate that the VTA is an important site of action for the control of food intake by endogenous amylin, as well as exogenous amylin analogs. Much of the present rat VTA data mirror human research findings using peripherally administered amylin analogs, including suppression of food intake via meal size reduction (Chapman et al, 2007; Smith et al, 2007) and reductions in palatable food intake (Smith et al, 2007). That the VTA directly mediates the food intake- and BW-suppressive effects of a peripherally administered amylin analog, and that amylin receptor signaling in the VTA reduces motivation to obtain a palatable sucrose reward, further highlights the possibility that VTA amylin receptors may mediate many of the observed intake-suppressive effects of systemically administered amylin analogs in humans. Given the importance of the VTA in mediating hedonic/motivational processes relating to food intake (Egecioglu et al,
2011; Vucetic and Reyes, 2010) and that amylin receptor activation in the VTA modulates motivation to obtain a palatable food, current data provide a compelling foundation for the examination of whether VTA amylin receptor signaling may be an effective pharmaceutical target for the treatment of human obesity.

\section{ACKNOWLEDGEMENTS}

Valuable technical assistance was provided by Adrian Arreola, Shaila Berlas, Lauren McGrath, Orianne Montaubin, and Christopher Turner. This research was supported by: DA22339 and DA18678 (R.C.P.); DA030445 (H.D.S.); and DK096139, DK093874, DK085435, and the Diabetes Research Center (DK19525; M.R.H.).

\section{DISCLOSURE}

The authors declare no conflict of interest.

\section{REFERENCES}

Alhadeff AL, Rupprecht LE, Hayes MR (2012). GLP-1 neurons in the nucleus of the solitary tract project directly to the ventral tegmental area and nucleus accumbens to control for food intake. Endocrinology 153: 647-658.

Andrews PL, Horn CC (2006). Signals for nausea and emesis: Implications for models of upper gastrointestinal diseases. Auton Neurosci 125: 100-115.

Baldo BA, Kelley AE (2001). Amylin infusion into rat nucleus accumbens potently depresses motor activity and ingestive behavior. Am J Physiol Regul Integr Comp Physiol 281: R1232-R1242.

Banks WA, Kastin AJ, Maness LM, Huang W, Jaspan JB (1995). Permeability of the blood-brain barrier to amylin. Life Sci 57: 1993-2001.

Bari AA, Pierce RC (2005). D1-like and D2 dopamine receptor antagonists administered into the shell subregion of the rat nucleus accumbens decrease cocaine, but not food, reinforcement. Neuroscience 135: 959-968.

Barth SW, Riediger T, Lutz TA, Rechkemmer G (2004). Peripheral amylin activates circumventricular organs expressing calcitonin receptor $\mathrm{a} / \mathrm{b}$ subtypes and receptor-activity modifying proteins in the rat. Brain Res 997: 97-102.

Beaumont K, Kenney MA, Young AA, Rink TJ (1993). High affinity amylin binding sites in rat brain. Mol Pharmacol 44: 493-497.

Becskei C, Riediger T, Zund D, Wookey P, Lutz TA (2004). Immunohistochemical mapping of calcitonin receptors in the adult rat brain. Brain Res 1030: 221-233.

Bello NT, Kemm MH, Moran TH (2008). Salmon calcitonin reduces food intake through changes in meal sizes in male rhesus monkeys. Am J Physiol Regul Integr Comp Physiol 295: R76-R81.

Bence KK, Delibegovic M, Xue B, Gorgun CZ, Hotamisligil GS, Neel BG et al (2006). Neuronal PTP1B regulates body weight, adiposity and leptin action. Nat Med 12: 917-924.

Butler PC, Chou J, Carter WB, Wang YN, Bu BH, Chang D et al (1990). Effects of meal ingestion on plasma amylin concentration in NIDDM and nondiabetic humans. Diabetes 39: 752-756.

Chapman I, Parker B, Doran S, Feinle-Bisset C, Wishart J, Lush CW et al (2007). Low-dose pramlintide reduced food intake and meal duration in healthy, normal-weight subjects. Obesity 15: 1179-1186.

Christopoulos G, Paxinos G, Huang XF, Beaumont K, Toga AW, Sexton PM (1995). Comparative distribution of receptors for 
amylin and the related peptides calcitonin gene related peptide and calcitonin in rat and monkey brain. Can J Physiol Pharmacol 73: 1037-1041.

Christopoulos G, Perry KJ, Morfis M, Tilakaratne N, Gao Y, Fraser NJ et al (1999). Multiple amylin receptors arise from receptor activity-modifying protein interaction with the calcitonin receptor gene product. Mol Pharmacol 56: 235-242.

De Jonghe BC, Horn CC (2008). Chemotherapy-induced pica and anorexia are reduced by common hepatic branch vagotomy in the rat. Am J Physiol Regul Integr Comp Physiol 294: R756-R765.

Egecioglu E, Skibicka KP, Hansson C, Alvarez-Crespo M, Friberg PA, Jerlhag E et al (2011). Hedonic and incentive signals for body weight control. Rev Endocr Metab Disord 12: 141-151.

Fukuda T, Hirai Y, Maezawa H, Kitagawa Y, Funahashi M (2013). Electrophysiologically identified presynaptic mechanisms underlying amylinergic modulation of area postrema neuronal excitability in rat brain slices. Brain Res 1494: 9-16.

Grill HJ (2006). Distributed neural control of energy balance: contributions from hindbrain and hypothalamus. Obesity 14(Suppl 5): 216S-221S.

Hayes MR, Leichner TM, Zhao S, Lee GS, Chowansky A, Zimmer D et al (2011). Intracellular signals mediating the food intakesuppressive effects of hindbrain glucagon-like peptide-1 receptor activation. Cell Metab 13: 320-330.

Hopkins TJ, Rupprecht LE, Hayes MR, Blendy JA, Schmidt HD (2012). Galantamine, an acetylcholinesterase inhibitor and positive allosteric modulator of nicotinic acetylcholine receptors, attenuates nicotine taking and seeking in rats. Neuropsychopharmacology 37: 2310-2321.

Johnson KH, O'Brien TD, Hayden DW, Jordan K, Ghobrial HK, Mahoney WC et al (1988). Immunolocalization of islet amyloid polypeptide (IAPP) in pancreatic beta cells by means of peroxidase-antiperoxidase (PAP) and protein A-gold techniques. Am J Pathol 130: 1-8.

Kahn SE, D’Alessio DA, Schwartz MW, Fujimoto WY, Ensinck JW, Taborsky GJ Jr et al (1990). Evidence of cosecretion of islet amyloid polypeptide and insulin by beta-cells. Diabetes 39: 634-638.

Kanoski SE, Rupprecht LE, Fortin SM, De Jonghe BC, Hayes MR (2012). The role of nausea in food intake and body weight suppression by peripheral GLP-1 receptor agonists, exendin-4 and liraglutide. Neuropharmacology 62: 1916-1927.

Lutz TA, Del Prete E, Scharrer E (1994). Reduction of food intake in rats by intraperitoneal injection of low doses of amylin. Physiol Behav 55: 891-895.

Lutz TA, Del Prete E, Scharrer E (1995a). Subdiaphragmatic vagotomy does not influence the anorectic effect of amylin. Peptides 16: 457-462.

Lutz TA, Del Prete E, Walzer B, Scharrer E (1996). The histaminergic, but not the serotoninergic, system mediates amylin's anorectic effect. Peptides 17: 1317-1322.

Lutz TA, Geary N, Szabady MM, Del Prete E, Scharrer E (1995b). Amylin decreases meal size in rats. Physiol Behav 58: 1197-1202.

Lutz TA, Mollet A, Rushing PA, Riediger T, Scharrer E (2001). The anorectic effect of a chronic peripheral infusion of amylin is abolished in area postrema/nucleus of the solitary tract (AP/ NTS) lesioned rats. Int J Obes Relat Metab Disord 25: 1005-1011.

Lutz TA, Senn M, Althaus J, Del Prete E, Ehrensperger F, Scharrer E (1998). Lesion of the area postrema/nucleus of the solitary tract (AP/NTS) attenuates the anorectic effects of amylin and calcitonin gene-related peptide (CGRP) in rats. Peptides 19: 309-317.

Lutz TA, Tschudy S, Rushing PA, Scharrer E (2000). Amylin receptors mediate the anorectic action of salmon calcitonin (sCT). Peptides 21: 233-238.

Mitchell D, Wells C, Hoch N, Lind K, Woods SC, Mitchell LK (1976). Poison induced pica in rats. Physiol Behav 17: 691-697.
Mollet A, Gilg S, Riediger T, Lutz TA (2004). Infusion of the amylin antagonist AC 187 into the area postrema increases food intake in rats. Physiol Behav 81: 149-155.

Mollet A, Meier S, Riediger T, Lutz TA (2003). Histamine H1 receptors in the ventromedial hypothalamus mediate the anorectic action of the pancreatic hormone amylin. Peptides 24: 155-158.

Mollet A, Lutz TA, Meier S, Riediger T, Rushing PA, Scharrer E (2001). Histamine H1 receptors mediate the anorectic action of the pancreatic hormone amylin. Am J Physiol Regul Integr Comp Physiol 281: R1442-R1448.

Narayanan NS, Guarnieri DJ, DiLeone RJ (2010). Metabolic hormones, dopamine circuits, and feeding. Front Neuroendocrinol 31: 104-112.

Oliver KR, Kane SA, Salvatore CA, Mallee JJ, Kinsey AM, Koblan $\mathrm{KS}$ et al (2001). Cloning, characterization and central nervous system distribution of receptor activity modifying proteins in the rat. Eur J Neurosci 14: 618-628.

Paxinos G, Chai SY, Christopoulos G, Huang XF, Toga AW, Wang HQ et al (2004). In vitro autoradiographic localization of calcitonin and amylin binding sites in monkey brain. $J$ Chem Neuroanat 27: 217-236.

Potes CS, Boyle CN, Wookey PJ, Riediger T, Lutz TA (2012). Involvement of the extracellular signal-regulated kinase $1 / 2$ signaling pathway in amylin's eating inhibitory effect. Am J Physiol Regul Integr Comp Physiol 302: R340-R351.

Potes CS, Turek VF, Cole RL, Vu C, Roland BL, Roth JD et al (2010). Noradrenergic neurons of the area postrema mediate amylin's hypophagic action. Am J Physiol Regul Integr Comp Physiol 299: R623-R631.

Reidelberger RD, Haver AC, Arnelo U, Smith DD, Schaffert CS, Permert J (2004). Amylin receptor blockade stimulates food intake in rats. Am J Physiol Regul Integr Comp Physiol 287: R568-R574.

Reidelberger RD, Kelsey L, Heimann D (2002). Effects of amylinrelated peptides on food intake, meal patterns, and gastric emptying in rats. Am J Physiol Regul Integr Comp Physiol 282: R1395-R1404.

Riediger T, Schmid HA, Lutz T, Simon E (2001). Amylin potently activates AP neurons possibly via formation of the excitatory second messenger cGMP. Am J Physiol Regul Integr Comp Physiol 281: R1833-R1843.

Riediger T, Schmid HA, Lutz TA, Simon E (2002). Amylin and glucose co-activate area postrema neurons of the rat. Neurosci Lett 328: 121-124.

Ritter RC, Slusser PG, Stone S (1981). Glucoreceptors controlling feeding and blood glucose: location in the hindbrain. Science 213: 451-452.

Roth JD, Hughes H, Kendall E, Baron AD, Anderson CM (2006). Antiobesity effects of the beta-cell hormone amylin in dietinduced obese rats: effects on food intake, body weight, composition, energy expenditure, and gene expression. Endocrinology 147: 5855-5864.

Rushing PA, Hagan MM, Seeley RJ, Lutz TA, D’Alessio DA, Air EL et al (2001). Inhibition of central amylin signaling increases food intake and body adiposity in rats. Endocrinology 142: 5035.

Rushing PA, Hagan MM, Seeley RJ, Lutz TA, Woods SC (2000). Amylin: a novel action in the brain to reduce body weight. Endocrinology 141: 850-853.

Ryan KK, Woods SC, Seeley RJ (2012). Central nervous system mechanisms linking the consumption of palatable high-fat diets to the defense of greater adiposity. Cell Metab 15: 137-149.

Scherbaum WA (1998). The role of amylin in the physiology of glycemic control. Exp Clin Endocrinol Diabetes 106: 97-102.

Schmidt HD, Famous KR, Pierce RC (2009). The limbic circuitry underlying cocaine seeking encompasses the PPTg/LDT. Eur J Neurosci 30: 1358-1369. 
Self DW (2004). Regulation of drug-taking and -seeking behaviors by neuroadaptations in the mesolimbic dopamine system. Neuropharmacology 47(Suppl 1): 242-255.

Seth R, Terry DE, Parrish B, Bhatt R, Overton JM (2012). Amylinleptin coadministration stimulates central histaminergic signaling in rats. Brain Res 1442: 15-24.

Sexton PM, Paxinos G, Kenney MA, Wookey PJ, Beaumont K (1994). In vitro autoradiographic localization of amylin binding sites in rat brain. Neuroscience 62: 553-567.

Singh-Franco D, Robles G, Gazze D (2007). Pramlintide acetate injection for the treatment of type 1 and type 2 diabetes mellitus. Clin Ther 29: 535-562.

Skibicka KP, Alhadeff AL, Grill HJ (2009). Hindbrain cocaine- and amphetamine-regulated transcript induces hypothermia mediated by GLP-1 receptors. J Neurosci 29: 6973-6981.
Skibicka KP, Grill HJ (2009). Hypothalamic and hindbrain melanocortin receptors contribute to the feeding, thermogenic, and cardiovascular action of melanocortins. Endocrinology 150: 5351-5361.

Smith SR, Blundell JE, Burns C, Ellero C, Schroeder BE, Kesty NC et al (2007). Pramlintide treatment reduces 24-h caloric intake and meal sizes and improves control of eating in obese subjects: a 6-wk translational research study. Am J Physiol Endocrinol Metab 293: E620-E627.

Vucetic Z, Reyes TM (2010). Central dopaminergic circuitry controlling food intake and reward: implications for the regulation of obesity. Wiley Interdiscip Rev Syst Biol Med 2: 577-593.

Wielinga PY, Alder B, Lutz TA (2007). The acute effect of amylin and salmon calcitonin on energy expenditure. Physiol Behav 91: 212-217.

Young A (2005). Receptor pharmacology. Adv Pharmacol 52: 47-65. 